\title{
Exploring the current application of professional competencies in human resource management in the South African context
}

\begin{tabular}{|c|c|}
\hline $\begin{array}{l}\text { Authors: } \\
\text { Nico Schutte } \\
\text { Nicolene Bark } \\
\text { Lidewey van }\end{array}$ & $\begin{array}{l}\text { huizen }^{1} \\
\text { er Sluis }\end{array}$ \\
\hline \multicolumn{2}{|c|}{$\begin{array}{l}\text { Affiliations: } \\
{ }^{1} \text { Department of Industrial } \\
\text { Psychology, North-West } \\
\text { University, Mafikeng Campus, } \\
\text { South Africa }\end{array}$} \\
\hline \multicolumn{2}{|c|}{$\begin{array}{l}{ }^{2} \text { Strategiese Talent } \\
\text { Management, Nyenrode } \\
\text { Business, the Netherlands }\end{array}$} \\
\hline \multicolumn{2}{|c|}{$\begin{array}{l}{ }^{3} \text { Optentia Research Unit, } \\
\text { North-West University, } \\
\text { South Africa }\end{array}$} \\
\hline \multicolumn{2}{|c|}{$\begin{array}{l}\text { Correspondence to: } \\
\text { Nicolene Barkhuizen }\end{array}$} \\
\hline \multicolumn{2}{|c|}{$\begin{array}{l}\text { Email: } \\
\text { nicolene.barkhuizen@nwu. } \\
\text { ac.za }\end{array}$} \\
\hline \multicolumn{2}{|c|}{$\begin{array}{l}\text { Postal address: } \\
\text { Department of Industrial } \\
\text { Psychology, North-West } \\
\text { University, Mafikeng Campus, } \\
\text { Mmabatho 2745, South Africa }\end{array}$} \\
\hline \multicolumn{2}{|c|}{$\begin{array}{l}\text { Dates: } \\
\text { Received: } 13 \text { June } 2015 \\
\text { Accepted: } 29 \text { Sept. } 2015 \\
\text { Published: } 30 \text { Nov. } 2015\end{array}$} \\
\hline \multicolumn{2}{|c|}{$\begin{array}{l}\text { How to cite this article: } \\
\text { Schutte, N., Barkhuizen, N., } \\
\text { \& Van der Sluis, L. (2015). } \\
\text { Exploring the current } \\
\text { application of professional } \\
\text { competencies in human } \\
\text { resource management } \\
\text { in the South African } \\
\text { context. SA Journal } \\
\text { of Human Resource } \\
\text { Management/SA Tydskrif vir } \\
\text { Menslikehulpbronbestuur, } \\
\text { 13(1), Art. \#724, } 9 \text { pages. } \\
\text { http://dx.doi.org/10.4102/ } \\
\text { sajhrm.v13i1.724 }\end{array}$} \\
\hline \multicolumn{2}{|l|}{ Read online: } \\
\hline 回祭回 & $\begin{array}{l}\text { Scan this QR } \\
\text { code with your } \\
\text { smart phone or } \\
\text { mobile device } \\
\text { to read online. }\end{array}$ \\
\hline
\end{tabular}

Authors:

Nico Schutte

Nicolene Barkhuizen ${ }^{1}$

Lidewey van der Sluis ${ }^{2,3}$

Affiliations:

University, Mafikeng Campus,

uth Africa

2Strategiese Talent

Management, Nyenrode

${ }^{3}$ Optentia Research Unit,

North-West University,

South Africa

Correspondence to:

Email:

nicolene.barkhuizen@nwu.

Postal address:

Department of Industria

Psychology, North-West

University, Mafikeng Campus,

Dates:

Received: 13 June 2015

Accepted: 29 Sept. 2015

How to cite this article:

Schutte, N., Barkhuizen, N

\& Van der Sluis, L. (2015).

application of professional

competencies in human

cource management

context. SA Journal

of Human Resource

13(1), Art. \#724, 9 pages.

http://dx.doi.org/10.4102/

sajhrm.v13i1.724

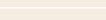

to read online.
Orientation: Human research (HR) practitioners have an important role to play in the sustainability and competitiveness of organisations. Yet their strategic contribution and the value they add remain unrecognised.

Research purpose: The main objective of this research was to explore the extent to which HR practitioners are currently allowed to display HR competencies in the workplace, and whether any significant differences exist between perceived HR competencies, based on the respondents' demographic characteristics.

Motivation for the study: Limited empirical research exists on the extent to which HR practitioners are allowed to display key competencies in the South African workplace.

Research approach, design, and method: A quantitative research approach was followed. A Human Resource Management Professional Competence Questionnaire was administered to HR practitioners and managers $(N=481)$.

Main findings: The results showed that HR competencies are poorly applied in selected South African workplaces. The competencies that were indicated as having the poorest application were talent management, HR metrics, HR business knowledge, and innovation. The white ethic group experienced a poorer application of all human research management (HRM) competencies compared to the black African ethnic group.

Practical/managerial implications: The findings of the research highlighted the need for management to evaluate the current application of HR practices in the workplace and also the extent to which HR professionals are involved as strategic business partners.

Contribution/value-add: This research highlights the need for the current application of HR competencies in South African workplaces to be improved.

\section{Introduction}

Human research (HR) practitioners have an important role to play in the sustainability of organisations and the subsequent economic growth of any country through its people (Sikora \& Ferris, 2014). The Global Competitiveness Report (2014) consistently gives South Africa poor rankings in terms of people development and HR practices. According to this report, South Africa is ranked 113 out of 144 countries for labour relations practices, 143rd for hiring and firing practices, due to rigidity, and 144th, for labour relations, due to significant tensions (World Economic Forum [WEF], 2014). Similarly, the Global Talent Competitive Index of 2014 ranked South Africa last out of 93 countries for labour-employer co-operation and 74 out 93 countries for effective hiring practices (Lanvin \& Evans, 2014). It therefore appears that the HR profession is slow in making a strategic contribution, and may not be maintaining effectiveness and relevance in the South African context (Boudreau \& Lawler, 2014).

The role that HR practitioners should play in organisations is the subject of an on-going debate (O'Brien \& Linehan, 2014). In line with the early work of Ulrich (1997), many scholars advocate that HR practitioners should be allowed to play a more strategic role in organisations (see De Nisi, Wilson \& Biteman, 2014; Sikora \& Ferris, 2014). Boudreau and Lawler (2014, p. 233) highlighted the fact that HR practitioners are not focusing on key strategic challenges in organisations such as 'improving productivity, increasing quality, facilitating mergers and acquisitions, managing knowledge, implementing change, developing business strategies and improving the ability of the organisation to execute strategies'. Moreover, Pohler and Willness (2014, p. 468) have stated that HR is being perceived as a 'low-level, reactive, and cost-focused administrative function

Copyright: ( 2015. The Authors. Licensee: AOSIS OpenJournals. This work is licensed under the Creative Commons Attribution License. 
with little autonomy ... and nothing more than a management control function'.

The available research has emphasised the impact of poor HR practices on both individual-level and organisationallevel outcomes in the South African context. Findings show that poor human capital practices have a negative impact on psychological contracts, organisational commitment, work engagement, motivation, job satisfaction, happiness, meaningfulness, well-being and the retention of employees in various settings (Barkhuizen, Mogwere \& Schutte, 2014; Diseko, 2015; Kekgonegile, 2015; Magolego, Barkhuizen \& Lesenyeho, 2013; Mtila, Barkhuizen \& Mokgele, 2013; Saurombe, 2015; Smit, 2014). Poor HR practices can have a significant impact on employee performance (Magolego et al., 2013; Masale, 2015) and, subsequently, on the quality of service delivery (Barkhuizen, Mogwere \& Schutte, 2014; Smit, 2014).

\section{Purpose}

In the light of the preceding, the need exists to explore the current application of human research management (HRM) competencies in the South African workplace. Most of the research in South Africa has focused on the roles, responsibilities, and practices of HR professionals. Given the current criticisms surrounding the HR function, research should focus on exploring the underpinning competencies that are the building blocks of effective HR practices (Abdullah, 2014). The lack of detailed empirical research on HR competencies and functions is widely recognised (Abdullah, 2014; Abdullah, Musa \& Ali, 2011; O'Brien \& Linehan, 2014). The main objective of this research was to explore the extent to which HR practitioners are currently allowed to display HR competencies in the workplace and whether any significant differences exist between perceived HR competencies, based on the respondents' demographic characteristics.

The next section of the article highlights some of the limited literature available on the application of HRM competencies in the South African workplace. Thereafter, the research approach and research method of the present study are discussed. The article concludes with a discussion of the research results as well as recommendations for further research.

\section{Literature review}

\section{Human research management role and competency requirements}

Most of the literature to date has been dominated by the extent to which HR practitioners are allowed to play a strategic versus an operational role in organisations. Many researchers have tested the original four-factor HR role model of Ulrich (1997) in various settings. According to this model, HR has four major roles to play, namely strategic partner, change agent (strategic roles), administrative expert and employee champion (operational roles). The activities of a strategic partner are aimed at developing an HR strategy that is aligned with the business strategy of the organisation. As change agents, HR practitioners focus on developing the capability of people and, consequently, the organisation. The role of an administrative expert focuses on the effective design and execution of HR processes, whereas the employee champion function deals with the daily needs and problems of employees.

In the light of the above model, Ulrich and Brockbank (2005) maintained that it is the role of the HR function to create value for investors and customers external to the organisation and to create value for line managers and employees inside the organisation. This value is created through the facilitation of HR practices that focus on:

- 'the flow of people' - ensuring the availability of talent to accomplish the organisational strategy;

- 'the flow of performance management' - promoting accountability for performance by defining and rewarding it;

- 'the flow of information' - ensuring that employees are aware of what is occurring in the organisation and can apply themselves to those things that create value; and

- 'the flow of work' - providing the governance processes, accountability, and physical setting that ensure quality results. (Ulrich \& Brockbank, 2005, p. 20)

Ulrich, Brockbank, Younger, and Ulrich (2013) recently revised the focus of the traditional model in order to adapt it to the changing business world. According to the revised model, HR practitioners as strategic business partners are 'high-performing HR professionals' who should understand the global context. The capacity-building role includes the ability of HR professionals to define and build organisational capabilities. HR, as a change agent, needs to assist organisations with effective change processes and structures, whereas the innovator and integrator roles require HR professionals to integrate $\mathrm{HR}$ business practices in order to support change initiatives.

The need for HR competence and professionalism is clearly highlighted in the revised roles proposed by Ulrich, Younger, Brockbank and Ulrich (2012). While the roles of HR have changed, the essential principles that guide HR (such as managing and developing the workforce) have remained unchanged (Boudreau \& Lawler, 2014). HR professionals therefore need to move away from traditional HR practices andbring about much-needed change in HR competence, skills, strategic roles, and professionalism to mobilise human capital and help to achieve organisational strategies.

HR practitioners in developing countries are still fulfilling mainly operational roles (i.e. Tessema \& Soeters, 2006), whereas most in developed countries are fulfilling more strategic roles (Du Plessis, Paine \& Botha, 2012; Thill, Venegas \& Groblshegg, 2014). In the South African context, Walters (2006) found that HR practitioners are mostly fulfilling the roles of administrative experts and employee champions, but are perceived as ineffective or incompetent in these roles. 
Steyn (2008) found similar results but discerned that some HR practitioners are moving towards fulfilling a more strategic role in organisations. A recent study by Abbott, Goosen and Coetzee (2013), however, pointed out that many HR practitioners in South Africa are still focusing on the role of employee advocate in the workplace without this role being extended.

The available research in the South African context points to a lack of HRM competence and subsequent poor practices being applied in the workplace. Schultz (2010) found that the HR department in a merged South African higher education institution displayed poor personal skills, HR business knowledge, and management skills. A study by van Wyk (2006) highlighted the lack of sufficient business knowledge among HR practitioners regarding a social responsibility issue such as HIV and AIDS. The HR practitioners, however, did acknowledge the importance of educating employees on social responsibility issues.

A study by Louw (2012) indicated that HR practitioners lack experience and competence in evaluating, executing, and reporting on HR interventions. As a result, HR practitioners cannot provide organisations with important data regarding the effectiveness of HR interventions (Field \& Louw, 2012; Salie \& Slechter, 2012). Furthermore, organisations are of the opinion that the data provided by HR practitioners are unreliable and lack integrity, and can therefore not be used (De Bruyn \& Roodt, 2009).

The effective talent management of employees also remains an area of great concern. Several studies pointed out the lack of talent management as evinced by poor training and development opportunities, poor performance management, poor workforce planning and acquisition, and ineffective retention strategies (Barkhuizen, 2015). These findings can be explained by the fact that confusion still prevails as to who should take responsibility for talent management in organisations. Other factors include the lack of management commitment to managing talent, bureaucratic organisational structures, and the non-recognition of HR's potential strategic value in a business partnership (SABPP, 2011).

Schutte (2015) recently developed and validated an HR competency model for the South African context. According to this model, HR professionals should be able to display HR competence in three domains: professional behaviour and leadership, service orientation and execution, and business intelligence. Professional behaviour and leadership refers to the suitability of HR professionals' activities, whether intentionally or unintentionally, in effecting environmental changes or conditions that reflect on the qualities associated with HR leadership and professional responsibilities. HR service orientation and execution involves the ability of HR practitioners to analyse situations or problems, make timely and sound decisions, construct plans, and achieve optimal results in response to the changing demands of customers. HR business intelligence refers to the ability of HR professionals to position themselves as an essential value-adding department of the organisation through the use of information in order to gain a competitive edge over competitors (see Schutte, 2015). This model is used in this study to assess the current application of HR practices in South African workplaces. In the light of the preceding, the following hypothesis has been set:

- Hypothesis 1: HR competencies are poorly applied in the South African context.

\section{Human resource competencies and background variables}

Limited research currently exists on the interactive relationships between HR competencies and background variables such as home language, ethnicity, job level, and outlook. Regarding age, research has shown that generation Y (born between 1978 and 1990; (Weingarten, 2009) places emphasis on sound HRM practices regarding compensation and training and development (Barkhuizen, 2014). A study by Du Plessis and Barkhuizen (2012) on the personal-level factors of HR practitioners showed that individuals aged 45 years and older displayed higher levels of hope and confidence than their younger counterparts. Further results showed that the white ethnic group scored higher on hope and confidence than the black ethic group, whereas the latter group displayed higher levels of resilience. Final results showed that HR practitioners employed at top management level displayed higher levels of psychological capital (i.e. hope, confidence, optimism, and resilience) than those employed at lower levels in the organisation (Du Plessis \& Barkhuizen, 2012).

In the light of the preceding the following hypothesis has been set:

- Hypothesis 2: Significant differences exist between HR practitioners and managers in the way in which they display HR competencies, based on their demographic characteristics.

\section{Method \\ Research approach}

A non-experimental, cross-sectional survey research strategy of enquiry was used in this study, based on the need for exploratory research on the application HR competencies in the South African workplace (Field, 2009). Cross-sectional research occurs when data are collected from the research participants at a single point in time or during a single, relatively brief period of time (Johnson \& Christensen, 2008).

\section{Measures}

\section{Sampling}

The respondents were HR officers and managers from various organisations in the private and public sectors who had knowledge of HRM processes in the workplace. The study employed purposive convenience sampling in which respondents were chosen based on their availability to 
participate and provide the desired information. A total of 800 questionnaires were distributed and 483 were returned. A total of 481 questionnaires were usable for analysis. This represented a $60.13 \%$ response rate. The demographic characteristics of the respondents in this sample, reported on in Table 1 below, are as follows: $55.1 \%$ were women, $70.5 \%$ spoke indigenous languages, and $76.9 \%$ were black Africans. A total of $29.5 \%$ of the respondents were aged 30-39 years, 35.8\% held a bachelor's degree as their highest level of educational qualification, and 31.1\% were employed at middle management level. Of the respondents, $37.8 \%$ had six to 15 years' work experience, $83.8 \%$ had been employed in their job for $0-10$ years and $64.0 \%$ had been employed by their current organisation for 0-10 years.

\section{Measuring instrument}

A Human Resource Management (HRM) Professional Competence Questionnaire (Schutte, 2015) was used in this study. This questionnaire consist of three sections and measures three core HR competency domains, namely, 'professional behaviour and leadership', 'service orientation and execution', and 'business intelligence'. The professional

TABLE 1: Demographic characteristics of the respondents.

\begin{tabular}{|c|c|c|c|}
\hline $\begin{array}{l}\text { Demographic } \\
\text { characteristics }\end{array}$ & Category & Frequency & Percentage \\
\hline \multirow[t]{2}{*}{ Gender } & Male & 213 & 44.3 \\
\hline & Female & 265 & 55.1 \\
\hline \multirow[t]{2}{*}{ Language } & English & 141 & 29.3 \\
\hline & Indigenous & 339 & 70.5 \\
\hline \multirow[t]{4}{*}{ Ethnicity } & African & 370 & 76.9 \\
\hline & Mixed race & 18 & 3.7 \\
\hline & Asian & 11 & 2.3 \\
\hline & White & 77 & 16.0 \\
\hline \multirow[t]{4}{*}{ Age } & $20-29$ & 59 & 12.3 \\
\hline & $30-39$ & 142 & 29.5 \\
\hline & $40-49$ & 139 & 28.9 \\
\hline & 50 and more & 68 & 14.1 \\
\hline \multirow[t]{4}{*}{ Qualifications } & Certificate & 78 & 16.2 \\
\hline & Diploma & 148 & 30.8 \\
\hline & Bachelor's degree & 172 & 35.8 \\
\hline & Postgraduate qualification & 70 & 14.6 \\
\hline \multirow[t]{5}{*}{ Job level } & Senior management & 38 & 7.9 \\
\hline & Middle management & 150 & 31.2 \\
\hline & Lower management & 86 & 17.9 \\
\hline & Supervisory & 77 & 16.0 \\
\hline & Operational & 113 & 23.5 \\
\hline \multirow{7}{*}{$\begin{array}{l}\text { Years' work } \\
\text { experience }\end{array}$} & $0-5$ & 75 & 15.6 \\
\hline & $6-10$ & 90 & 18.7 \\
\hline & $11-15$ & 92 & 19.1 \\
\hline & $16-20$ & 58 & 12.1 \\
\hline & $21-25$ & 78 & 16.2 \\
\hline & $26-30$ & 54 & 11.2 \\
\hline & 30 years or more & 31 & 6.4 \\
\hline \multirow[t]{3}{*}{ Years in job } & $0-10$ & 403 & 83.8 \\
\hline & $11-20$ & 60 & 12.5 \\
\hline & $21-30$ & 17 & 3.5 \\
\hline \multirow[t]{3}{*}{ Years in organisation } & $0-10$ & 308 & 64.0 \\
\hline & $11-20$ & 91 & 18.9 \\
\hline & $21-30$ & 79 & 16.4 \\
\hline
\end{tabular}

behaviour and leadership competency consists of four subcompetencies, namely, leadership and personal credibility (8 items), solution creation (4 items), interpersonal communication ( 7 items), and innovation (6 items). The service orientation and execution competency consists of four sub-competencies, namely, talent management (9 items), HR risk (5 items), HR metrics (6 items), and HR service delivery (6 items). The business intelligence competency consists of four sub-competencies, namely, strategic impact (11 items), HR business knowledge (10 items), business acumen (6 items), and HR technology (3 items).

Responses were measured on a five-point Likert scale ranging from 'Never' (1) to 'Always' (5). The questionnaire has been validated for the South African context, and showed excellent reliabilities of above 0.90 for the underlying factors (Schutte, 2015).

\section{Research procedure}

Permission was obtained from the necessary authorities prior to the administration of the questionnaire. Hardcopy and soft-copy surveys were distributed to the relevant participants. Ethical clearance was obtained prior to the administration of the surveys. Confidentiality was maintained at all times.

\section{Statistical analyses}

Data were analysed with the aid of SPSS Inc. (2015). Exploratory factor analyses were used to determine the underlying factor structure. Descriptive statistics (i.e. means, standard deviation, and kurtosis) were used to analyse the data. Multivariate analysis of variance (MANOVA) was used to determine the significance of differences between the dimensions of the HRM Professional Competence Model for the demographic groups. MANOVA tests whether mean differences among groups in a combination of dependent variables are likely to have occurred by chance (Field, 2009). When an effect was significant in MANOVA, one-way Analysis of variance (ANOVA) was used to discover which dependent variables had been affected. T-tests were done to assess the differences between the groups in the sample. For purposes of the present research, we used Cohen's (1988, p. 283) guidelines for the interpretation of effect sizes: 0.0099 constitutes a small effect, 0.0588 a medium effect, and 0.1379 is a large effect.

\section{Results}

The KMO analyses showed the following measures of sampling adequacy: professional behaviour and leadership - 0.954, service orientation and execution - 0.936, and business intelligence -0.950 . These results were acceptable according to the guideline of a $\mathrm{KMO}$ higher than 0.6 being adequate for factor analysis (Hair, Black, Babin \& Anderson, 2010). The results of the factor analyses are reported next. 


\section{Factor analyses}

\section{Professional behaviour and leadership}

Exploratory factor analyses, using principal component analyses, were done on the 25 items of the 'Professional behaviour and leadership' section of the questionnaire. The initial analyses revealed that four factors could be extracted, based on the eigenvalues. A subsequent factor analysis with direct Oblimin rotation revealed four underlying factors, which explained $82.020 \%$ of the variance. Four items were deleted because of problematic loadings. The factors were labelled: 'interpersonal communication' (Factor 1), 'leadership and personal credibility' (Factor 2), 'solution creation and implementation' (Factor 3), and 'innovation' (Factor 4). The items showed acceptable loadings.

\section{Service orientation and execution}

An exploratory factor analysis, using principal component analyses, was done on the 26 items of the 'Service orientation and execution' section of the questionnaire. The initial analyses revealed that four factors could be extracted, based on the eigenvalues. A subsequent principal component factor analysis, using varimax rotation, was done to specify the four underlying factors. Six items were deleted due to problematic loadings. The four factors explained $81.636 \%$ of the variance for the measure. The factors were labelled 'talent management' (Factor 1), 'HR service delivery' (Factor 2),
'HR metrics' (Factor 3), and 'HR risk' (Factor, 4). The items showed acceptable loadings.

\section{Business intelligence}

An exploratory factors analysis, using principal component analyses, was done on the 30 items of the 'Business intelligence' section of the questionnaire. The initial analyses revealed that four factors could be extracted, based on the eigenvalues. A subsequent principal component factor analysis, using varimax rotation, was done to specify the four underlying factors. The four factors explained $74.417 \%$ of the variance. Two items were deleted because of problematic loadings. The factors were labelled as follows: 'HR business knowledge' (Factor 1), 'strategic impact' (Factor 2), 'business acumen' (Factor 3) and 'HR technology' (Factor 4). The items showed acceptable loadings.

The descriptive statistics of the factors are reported on in Table 2.

The findings, provided in Table 2, showed acceptable to excellent reliabilities for all the dimensions of the HRM Professional Competence Model. The respondents indicated that most of the dimensions are applied moderately. The competencies that were indicated as having the poorest application were talent management, HR metrics, HR business knowledge, and innovation.

TABLE 2: Descriptive statistics of the factors.

\begin{tabular}{|c|c|c|c|c|c|c|}
\hline HR professional competencies & HR professional sub-competencies & Mean & SD & Skewness & Kurtosis & $\alpha$ \\
\hline \multirow[t]{4}{*}{ Professional behaviour and leadership } & Leadership and personal credibility & 3.3059 & 0.94722 & -0.289 & -0.042 & 0.960 \\
\hline & Solution creation & 3.2469 & 0.96972 & -0.128 & -0.114 & 0.882 \\
\hline & Interpersonal communication & 3.3358 & 1.03634 & -0.075 & -0.649 & 0.959 \\
\hline & Innovation & 2.9508 & 1.04200 & 0.268 & -0.598 & 0.895 \\
\hline \multirow[t]{3}{*}{ Service orientation and execution } & Talent management & 2.7914 & 1.05855 & 0.098 & -0.775 & 0.942 \\
\hline & HR risk & 3.2416 & 0.92427 & $0-.073$ & -0.151 & 0.916 \\
\hline & HR service delivery & 3.3714 & 0.96516 & -0.486 & -0.109 & 0.945 \\
\hline \multirow[t]{4}{*}{ Business intelligence } & Strategic impact & 3.1335 & 0.81812 & -0.115 & 0.343 & 0.933 \\
\hline & HR business knowledge & 3.4940 & 0.92866 & -0.379 & -0.077 & 0.953 \\
\hline & HR business acumen & 2.9567 & 0.95180 & 0.203 & -0.168 & 0.944 \\
\hline & HR technology & 3.0825 & 1.00618 & -0.260 & -0.282 & 0.915 \\
\hline
\end{tabular}

SD, standard deviation

TABLE 3: Gap analyses: Current application versus the importance of human resource management competencies.

\begin{tabular}{|c|c|c|c|c|c|c|}
\hline HR professional competencies & HR professional sub-competencies & Mean importance & Mean current & Difference & $p$ & eta \\
\hline \multirow[t]{4}{*}{ Professional behaviour and leadership } & Leadership and personal credibility & 4.0257 & 3.3059 & 0.7198 & 0.422 & 0.069 \\
\hline & Solution creation & 3.9858 & 3.2469 & 0.7389 & 0.083 & 0.050 \\
\hline & Interpersonal communication & 4.0304 & 3.3358 & 0.6946 & 0.351 & 0.052 \\
\hline & Innovation & 3.9586 & 2.9508 & 1.0078 & 0.387 & 0.027 \\
\hline \multirow[t]{4}{*}{ Service orientation and execution } & Talent management & 3.918 & 2.7914 & 1.1266 & 0.368 & 0.075 \\
\hline & HR risk & 3.966 & 3.2416 & 0.7244 & 0.224 & 0.048 \\
\hline & HR metrics & 3.8274 & 2.8101 & 1.0173 & 0.368 & 0.049 \\
\hline & HR service delivery & 3.9184 & 3.3714 & 0.547 & 0.231 & 0.057 \\
\hline \multirow[t]{4}{*}{ Business intelligence } & Strategic Impact & 3.9181 & 3.1335 & 0.7846 & 0.287 & 0.091 \\
\hline & HR business knowledge & 4.0582 & 3.494 & 0.5642 & 0.753 & 0.057 \\
\hline & HR business acumen & 3.9716 & 2.9567 & 1.0149 & 0.682 & 0.023 \\
\hline & HR technology & 3.8723 & 3.0825 & 0.7898 & 0.546 & 0.023 \\
\hline
\end{tabular}


Next, a gap analysis was performed to determine whether significant differences existed between the importance and the current application of the HRM dimensions. The results, provided in Table 3, showed no significant differences between the current applications versus the importance of HRM competencies.

Next, the findings of the MANOVA of the differences between the current application of the HRM professional dimensions (i.e. professional behaviour and leadership; service orientation and delivery; business intelligence) and demographics groups are reported.

\section{Multivariate analysis of variance analyses Professional behaviour and leadership}

The findings in Table 4 show that the respondents differed significantly regarding the current application of $\mathrm{HR}$ competencies, according to the variables home language, ethnicity, and job level. Further post hoc analyses showed no significant differences related to the variables home language and ethnicity. The remainder of the findings of the post hoc analyses are reported below.

Wilks's lambda for the variable home language was 0.936 $\left[F_{(1,481)}=8.090 ; p \leq 0.05\right]$. Analysis of each dependent variable, using a Bonferroni adjusted alpha level of 0.025, showed that the groups differed regarding leadership and personal credibility $\left[F_{(3,481)}=6.565 ; p \leq 0.05\right.$; partial $\left.\eta^{2}=0.026\right]$, solution creation $\left[F_{(3,481)}=16.859 ; p \leq 0.05\right.$; partial $\left.\eta^{2}=0.023\right]$, interpersonal communication $\left[F_{(3,481)}=3.972 ; p \leq 0.05\right.$; partial $\left.\eta^{2}=0.062\right]$, and innovation $\left[F_{(3,481)}=8.203 ; p \leq 0.05\right.$; partial $\eta^{2}=$ 0.029). The English-language group were of the view that HR practitioners display the leadership competencies solution creation, interpersonal communication, and innovation less effectively, compared to respondents from the indigenous languages group. The effects were small.

Wilks's lambda for the variable ethnicity was $0.933\left[F_{(1,481)}=\right.$ 2.067; $p \leq 0.05$ ]. Analysis of each dependent variable, using a Bonferroni adjusted alpha level of 0.025 , showed that the groups differed in terms of leadership and personal credibility $\left[F_{(3,481)}=\right.$ 3.699; $p \leq 0.05$; partial $\left.\eta^{2}=0.030\right]$, solution creation $\left[F_{(3,481)}=\right.$ $3.783 ; p \leq 0.05 ;$ partial $\left.\eta^{2}=0.031\right]$, and innovation $\left[F_{(3,481)}=3.296\right.$; $p \leq 0.05$; partial $\left.\eta^{2}=0.027\right]$. The black African ethnic group rated HR practitioners' display of the leadership competencies solution creation and innovation as more effective than the white ethnic group did. The effects were small.

\section{Service orientation and execution}

The findings, provided in Table 5, show that the respondents differed significantly regarding the current application of HR competencies, according to the variables home language, age, qualifications, and job level. Further post hoc analyses showed no significant differences according to age and job level. The remainder of the findings of the post hoc analyses is reported below.

Wilks's Lambda for home language was $0.953\left[F_{(1,481)}=\right.$ 5.879; $p \leq 0.05$ ]. Analysis of each dependent variable, using

TABLE 4: Multivariate analysis of variance analyses - Professional behaviour and leadership and demographic groups.

\begin{tabular}{|c|c|c|c|c|c|c|}
\hline Demographic characteristics & Value & $F$ & Hypothesis $d f$ & Error $d f$ & Significance & Partial eta squared \\
\hline Gender & 0.985 & 1.801 & 4.000 & 473.000 & 0.127 & 0.015 \\
\hline Home language & 0.936 & 8.090 & 4.000 & 475.000 & 0.000 & 0.064 \\
\hline Ethnicity & 0.933 & 2.067 & 16.000 & 1430.401 & 0.008 & 0.017 \\
\hline Age & 0.966 & 1.167 & 12.000 & 1061.238 & 0.302 & 0.011 \\
\hline Qualification & 0.956 & 1.730 & 12.000 & 1219.983 & 0.055 & 0.015 \\
\hline Job level & 0.943 & 1.686 & 16.000 & 1393.741 & 0.043 & 0.015 \\
\hline Years' work experience & 0.935 & 1.138 & 28.000 & 1685.215 & 0.282 & 0.017 \\
\hline Years in current job & 0.972 & 1.706 & 8.000 & 948.000 & 0.093 & 0.014 \\
\hline Years in current organisation & 0.977 & 1.374 & 8.000 & 944.000 & 0.204 & 0.012 \\
\hline
\end{tabular}

Bold indicates significant differences.

TABLE 5: Multivariate analysis of variance analyses - Service orientation and execution and demographic groups.

\begin{tabular}{|c|c|c|c|c|c|c|}
\hline Demographic characteristics & Value & $F$ & Hypothesis $d f$ & Error $d f$ & $P$ & Partial eta squared \\
\hline Gender & 0.988 & 1.454 & 4.000 & 473.000 & 0.215 & 0.012 \\
\hline Home language & 0.953 & 5.879 & 4.000 & 475.000 & 0.000 & 0.047 \\
\hline Ethnicity & 0.953 & 1.406 & 16.000 & 1430.401 & 0.130 & 0.012 \\
\hline Age & 0.936 & 2.255 & 12.000 & 1061.238 & 0.008 & 0.022 \\
\hline Qualification & 0.981 & 0.745 & 12.000 & 1219.983 & 0.707 & 0.006 \\
\hline Job level & 0.952 & 1.423 & 16.000 & 1393.741 & 0.122 & 0.012 \\
\hline Years' work experience & 0.920 & 1.404 & 28.000 & 1685.215 & 0.078 & 0.021 \\
\hline Years in current job & 0.965 & 2.132 & 8.000 & 948.000 & 0.031 & 0.018 \\
\hline Years in current organisation & 0.976 & 1.450 & 8.000 & 944.000 & 0.172 & 0.012 \\
\hline
\end{tabular}

Bold indicates significant differences. 
a Bonferroni adjusted alpha level of 0.025 , showed that the groups differed regarding talent management $\left[F_{(3,481)}=8.416\right.$; $p \leq 0.05 ;$ partial $\left.\eta^{2}=0.017\right]$, HR risk $\left[F_{(3,481)}=21.816 ; p \leq 0.05\right.$ partial $\left.\eta^{2}=0.044\right]$, HR metrics $\left[F_{(3,481)}=13.836 ; p \leq 0.05\right.$; partial $\left.\eta^{2}=0.028\right]$, and HR service delivery $\left[F_{(3,481)}=6.194 ; p \leq 0.05\right.$; partial $\left.\eta^{2}=0.013\right]$. The English-language group indicated that HR practitioners display the competencies talent management, HR risk, HR metrics, and HR service delivery less effectively, compared to the indigenous languages group. The effects were small.

\section{Business intelligence}

The findings, provided in Table 6, show that the respondents differed significantly regarding the current application of business intelligence, based on the variables home language and age. Further post hoc analyses showed no significant differences according to the variable age. The remainder of the findings of the post hoc analyses is reported below.

Wilks's Lambda for home language was $0.957\left[F_{(3,481)}=\right.$ 5.322; $p \leq$ 0.05]. Analysis of each dependent variable, using a Bonferroni adjusted alpha level of 0.025, showed that the groups differed regarding strategic impact $\left[F_{(3,481)}=\right.$ 7.749; $p \leq 0.05$; partial $\left.\eta^{2}=0.024\right]$, HR business knowledge $\left[F_{(3,481)}=17.002 ; p \leq 0.05 ;\right.$ partial $\left.\eta^{2}=0.041\right]$, business acumen $\left[F_{(3,481)}=8.978 ; p \leq 0.05 ;\right.$ partial $\left.\eta^{2}=0.021\right]$, and HR technology $\left[F_{(3,481)}=8.934 ; p \leq 0.05 ;\right.$ partial $\left.\eta^{2}=0.018\right]$. The Englishlanguage group indicated that HR practitioners display the competencies strategic impact, HR business knowledge, business acumen, and HR technology less effectively, compared to the indigenous languages group. The effects were small.

\section{Discussion}

The main objective of this research is to explore the extent to which HR practitioners display HR competencies in publicand private-sector organisations. Secondly, this research aimed to determine whether significant differences exist between the respondents' perceptions of HR competencies, based on their demographic characteristics.

The findings of this research show that HR practitioners are allowed to display the defined HR competencies only to a low or moderate extent in organisations. More specifically, HR practitioners are limited in applying innovation, talent management, HR metrics, and HR business knowledge. These results concur with those of previous studies which found that HR professionals are still not allowed to play a strategic role in South African organisations and, as a result, HR competencies and practices are poorly applied (see Barkhuizen, 2015; Schultz, 2010; van Wyk, 2006; Walters, 2006).

These findings are concerning, given that the respondents ranked all the measured HR competencies as important. Although the results revealed no significant differences between the current application of HR competencies versus their importance, public-sector organisations should improve their current HR practices to enhance both individual and organisational outcomes.

The findings show that the respondents differed significantly in their perceptions of the current application of HR competencies, based on the variable home language. The predominant finding in this research is that significant differences existed between respondents from the Englishlanguage group (representative of the white ethnic group) and respondents from the indigenous languages group (representative of the black African ethnic group). The English-language group were of the view that all HR competencies (i.e. leadership and personal credibility, solution creation, interpersonal communication, innovation, talent management, HR risk, HR metrics, HR service delivery, strategic impact, HR business knowledge, business acumen, and HR technology) are significantly less effectively applied, compared to the view of the indigenous languages group.

These findings are a reflection of the current realties in the South African context. As mentioned previously, the public sector has been subjected to numerous changes since the establishment of the new South African democratic dispensation in 1994, which resulted in various practices to address the past imbalances in the workforce. Affirmative action resulted in numerous white employees being retrenched to ensure employment equity in the government sector. As a result, the remaining minority of members of the white ethnic group may view the application of HR practices

TABLE 6: Multivariate analysis of variance analyses - Business intelligence and demographic groups.

\begin{tabular}{llcccc}
\hline Demographic characteristics & Value & $\boldsymbol{F}$ & Hypothesis $d \boldsymbol{f}$ & Error $d \boldsymbol{f}$ & Partial eta squared \\
\hline Gender & 0.995 & 0.648 & 4.000 & 472.000 & 0.629 \\
Home language & 0.957 & 5.322 & 4.000 & 474.000 & 0.000 \\
Ethnicity & 0.950 & 1.521 & 16.000 & 1427.346 & 0.043 \\
Age & 0.940 & 2.070 & 12.000 & 1058.592 & 0.084 \\
Qualification & 0.975 & 0.965 & 12.000 & 1217.337 & 0.016 \\
Job level & 0.955 & 1.320 & 16.000 & 1390.686 & 0.480 \\
Years' work experience & 0.926 & 1.303 & 28.000 & 1681.609 & 0.176 \\
Years in current job & 0.983 & 1.035 & 8.000 & 946.000 & 0.134 \\
Years in current organisation & 0.987 & 0.748 & 8.000 & 942.000 & 0.011 \\
\hline
\end{tabular}

Bold indicates significant differences. 
as less effective, compared to other ethnic groups. These results, however, need to be interpreted with caution. More research is needed to clarify the significant differences of viewpoint between white and black ethic groups regarding the application of HR practices. These results confirm that significant differences may exist between respondents in their perceptions of the application of HR competencies and practices in the South African workplace (see Du Plessis \& Barkhuizen, 2012).

\section{Practical implications}

This research makes important theoretical, methodological, and practical contributions. From a theoretical perspective, it research adds to the body of emerging research on the current status of HRM in South African organisations. Many researchers have debated the application of HR practices in South African workplaces without empirically investigating them. The present research provides sound empirical knowledge on the competency requirements and subsequent effectiveness of HR practitioners in South African workplaces. This research makes an important methodological contribution by demonstrating the utility of a new measure of HR competencies in the South African workplace. This research also adds important practical value by highlighting the problematic areas of HRM in public- and private-sector organisations and by making suggestions for their improvement in order to ensure HR competence in service delivery.

\section{Limitations and recommendations}

This research has some limitations. First, the convenience sampling technique used limits the research in terms of generalising its findings to the total population. Second, this research used a cross-sectional design, which limited the diagnosis of cause-and-effect relationships between variables. Future research could benefit from longitudinal studies to predict the cause and effect of findings, especially among different ethnic groups in South Africa. Future research could also benefit from cross-national studies to benchmark HR practices with those of other African countries. Such research would benefit Africa as a developing continent, as sound HR practices play a key role in the competiveness and sustainability of organisations and countries. Future research could also expand on the current study by including individual-level and organisational-level variables to predict the key outcomes of HR competencies in South African workplaces.

\section{Conclusion}

In conclusion, this research highlights the importance of the HR function in the South African workplace context. Organisations can reap the long-term benefits from a strategic partnership with HR in the form of competitiveness and sustainability. The findings of this research reiterate the need for business leaders to take stock of their current HR practices and the extent to which HR practitioners are allowed to play a strategic role in their organisations.

\section{Acknowledgements}

\section{Competing interests}

The authors declare that they have no financial or personal relationships which may have inappropriately influenced them in writing this article.

\section{Authors' contributions}

N.S. (North-West University) is an associate professor and a PhD student. This article, which he compiled, is based on his second PhD. N.B. (North-West University) was the supervisor for this study and L.v.d.S. (Nyenrode Business) the co-supervisor. Both supervisors provided editorial inputs for the article.

\section{References}

Abbott, P., Goosen, X., \& Coetzee, J. (2013). The human resource function contribution to human development in South Africa. SA Journal of Human Resource Management/SA Tydskrif vir Menslikehulpbronbestuur, 11(1), 14. http://dx.doi org/10.4102/sajhrm.v11i1.408

Abdullah, A.H. (2014). Development of an HR practitioner competency model and determining the important business competencies: An empirical study in Malaysia. International Journal of Management Excellence, 3, 446-461.

Abdullah, A.H., Musa, R., \& Ali, J.H. (2011). The development of human resource practitioner competency model perceived by Malaysian human resource practitioners and consultants: A structural equation modeling (SEM) approach International Journal of Business and Management 6, 241-255. http://dx.doi. org/10.5539/ijbm.v6n11p240

Barkhuizen, E.N. (2014). Project talent management In $\mathrm{Y}$ du Plessis (Ed.) Project management: A behavioural perspective: Theoretical principles, advanced practices and cases (Chapter 13, pp. 370-408). Cape Town: Pearson advanced prac
Education.

Barkhuizen, E.N. (2015). Talent management: The catalyst for the 21st century business world. Retrieved April 30, 2015, from http://www.nwu.ac.za/sites/www. nwu.ac.za/files/files/mc/documents/2015\%20-\%20INAUGURAL\%20 LECTURE\%2OPROF\%20BARKHUIZEN.pdf

Barkhuizen, E.N., Mogwere, P., \& Schutte, N.E. (2014). Talent management, work engagement and service quality orientation of support staff in a higher education institution. Mediterranean Journal of Social Sciences, 5, 69-77. http://dx.doi. org/10.5901/mjss.2014.v5n4p69

Barkhuizen, E.N., Welby-Cooke, G., Schutte, N.E., \& Stanz, K.J. (2014). Talent management and leadership reciprocity: The case of the South African aviation industry. Mediterranean Journal of Social Sciences, 5, 11-17. http://dx.doi. org/10.5901/mjss.2014.v5n9p11

Boudreau, J., \& Lawler, E.E. (2014). Stubborn traditionalism in HRM: Causes and consequences. Human Resource Management Review, 24, 232-244. http:// dx.doi.org/10.1016/j.hrmr.2014.03.005

Cohen, J. (1988). Statistical power analysis for the behavioral sciences. (2nd edn.) Orlando, FL: Academic Press.

De Bruyn, L., \& Roodt, G. (2009). Applying the criteria of Ulrich and Brockbank for the assessment of the role of human resources as a strategic business partner in a mining company. SA Journal of Human Resource Management, 7(1), Art. \#200, 11 pages. http://dx.doi.org/10.4102/sajhrm.v7i1.200

DeNisi, A.S., Wilson, M.S., \& Biteman, J. (2014). Research and practice in HRM: A historical perspective. Human Resource Management Review, 24, 219-231. http://dx.doi.org/10.1016/j.hrmr.2014.03.004

Diseko. (2015). Talent management as a predictor of turnover intentions of teachers. Unpublished master's dissertation, North-West University, Mafikeng, South Africa.

Du Plessis, Y., \& Barkhuizen, E.N. (2012). Psychological capital: A requisite for organisational performance in South Africa. The South African Journal of Economic and Management Sciences, 15, 16-30.

Du Plessis, A.J., Paine, S., \& Botha, C.J. (2012). The role of human resource practitioners maintaining sustainability in organisations: Some empirical evidence of expectations, challenges and trends. International Journal of Contemporary Business Studies, 3, 16-34.

Field, A. (2009). Discovering statistics using SPSS. (3rd edn.). London: Sage.

Field, C., \& Louw, J. (2012). A theory-driven evaluation of a wellness initiative. SA Journal of Human Resource Management/SA Tydskrif vir Menslikehulpbronbestuur, 10(3), Art. \#427, 8 pages. http://dx.doi.org/10.4102/sajhrm.v10i3.427

Hair, J.F., Black, W.C., Babin, B.J., \& Anderson, R.E. (2010). Multivariate data analysis: A global perspective. (7th edn.). Upper Saddle River, N Je: Pearson Education.

Johnson, L.T.B., \& Christensen, L. (2008). Educational research: Quantitative \& qualitative and mixed approaches. (3rd edn.). London: SAGE Publications. 
Kekgonegile, K. (2015). The relationship between talent management, burnout and turnover of mining employees in Botswana. Unpublished master's dissertation, North-West University, Mafikeng, South Africa.

Lanvin, B., \& Evans, P. (Eds.). (2014). The global talent competitiveness index: Growing talent for today and tomorrow. Singapore: Adecco.

Louw, J. (2012). Programme evaluation: Can it improve human resource management practice? SA Journal of Human Resource Management, 10(3), Art. \#428, 5 pages. http://dx.doi.org/10.4102/sajhrm.v10i3.428

Magolego. H., Barkhuizen, E.N., \& Lesenyeho, D.L. (2013). Talent management and job performance: The mediating role of job satisfaction. In S.M. Lee \& G. Roodt (Eds.), 30th Pan Pacific Conference (pp. 132-135). Johannesburg, South Africa: PPBA. ISBN: 1-931649-27-3.

Masale, L. (2015). Talent management as a predictor of council employees' performance in a local government institution in Botswana. Unpublished master's dissertation, North-West University, Mafikeng, South Africa.

Mtila, J., Barkhuizen, E.N., \& Mokgele, R. (2013). Exploring the application of talent management practices in a local government institution. In S.M. Lee \& G. Roodt (Eds.), 30th Pan Pacific Conference (pp. 66-68). Johannesburg, South Africa: PPBA. ISBN: 1-931649-27-3.

O'Brien, E., \& Linehan, C. (2014). A balancing act: Emotional challenges in the HR role Journal of Management Studies, 51(8), 1257-1285. http://dx.doi.org/10.1111/ joms.12098

Pohler, D., \& Willness, C. (2014). Balancing interests in the search for occupational legitimacy: The HR professionalization project in Canada. Human Resource Management, 53, 467-488. http://dx.doi.org/10.1002/hrm.21579

SABPP. (2011). Annual stakeholder report. Johannesburg: SABPP.

Salie, S., \& Schlechter, A. (2012). A formative evaluation of a staff reward and recognition programme. SA Journal of Human Resource Management, 10(3), Art \#422, 11 pages. http://dx.doi.org/10.4102/sajhrm.v10i3.422

Saurombe, M. (2015). Talent management as a predictor of positive work related outcomes for academic staff in South African higher education institutions. Unpublished master's dissertation, North-West University, Mafikeng, South Africa.

Schultz, C.M. (2010). HR competencies at a merged higher education institution SA Journal of Human Resource Management, 8(1), 8 pages. http://dx.doi. org/10.4102/sajhrm.v8i1.225

Schutte, N.E. (2015). The development of a human resource management competency measure: A pilot study. Unpublished manuscript, Mafikeng, South Africa.
Sikora, D.M., \& Ferris, G.R. (2014). Strategic human resource practice implementation: The critical role of line management. Human Resource Management Review, 24, 271-281. http://dx.doi.org/10.1016/j.hrmr.2014.03.008

Smit, A. (2014). The relationship between talent management, motivation and service orientation of support staff in a higher education institution. Unpublished master's dissertation, Polytechnic of Namibia, Windhoek, Namibia.

SPSS Inc. (2015). SPSS 22.0 for Windows. Chicago, IL: Author.

Steyn, A. (2008). The strategic role of human resource professionals in a South African context. Unpublished master's dissertation, University of Pretoria, Pretoria, South Africa.

Tessema, M.T., \& Soeters, J.L. (2006). Challenges and prospects of HRM in developing countries: Testing the HRM-performance link in the Eritrean civil service. International Journal of Human Resource Management, 17, 86-105. http://dx.doi. org/10.1080/09585190500366532

Thill, K., Venegas, B.C., \& Groblschegg, S. (2014). HR roles and activities. Empirical results from the DACH region and implications for a future development of the HR profession. International Journal of Business and Management, 4, 97-109.

Ulrich, D. (1997). Human resource champions: The next agenda for adding value and delivering results. Boston: Harvard Business School Press.

Ulrich, D., \& Brockbank, W. (2005). The HR value proposition. Boston: Harvard Business School Press.

Ulrich, D., Brockbank, W., Younger, J., \& Ulrich, M. (2013). Global HR competencies: Mastering competitive value from the outside in. New York: McGraw Hill.

Ulrich, D., Younger, J., Brockbank, W., \& Ulrich, M. (2012). HR talent and the new HR competencies. Strategic HR Review, 11, 217-222. http://dx.doi. org/10.1108/14754391211234940

Van Wyk, C.D. (2006). Human resource practitioners' perceptions of their role and responsibility in managing HIV/AIDS in the industry. SA Journal of Human Resource Management, 4, 29-35. http://dx.doi.org/10.4102/sajhrm.v4i3.10

Walters, G. (2006). The effectiveness of a human resources function within a public utility. Unpublished master's dissertation, Department of Industrial Psychology, University of South Africa, Pretoria, South Africa.

Weingarten, R. (2009). Four generations, one workplace: A gen $X-Y$ staff nurse's view of team building in the emergency department. Journal of Emergency Nursing: JEN: Official Publication of the Emergency Department Nurses Association, 35(1), 27-30. PMID: 19203677, http://dx.doi.org/10.1016/j.jen.2008.02.017

World Economic Forum (WEF). (2014). Global competitiveness report 2013-2014. Geneva: WEF. 